[CL]

\title{
Discordant Silurian paleolatitudes for central Newfoundland: New paleomagnetic evidence from the Springdale Group
}

\author{
Stephen S. Potts, Ben A. van der Pluijm and Rob Van der Voo \\ Department of Geological Sctences, Uniterstty of Michigan, Ann Arbor, MI 48109-1063, USA
}

Recerved May 13, 1993, revision accepted September 13, 1993

\begin{abstract}
Ancient remanences are retained by the Early Sılurıan $(429+6 /-5 \mathrm{Ma})$ mafic volcanıcs of the Springdale Caldera (five sites) and the overlying red beds (seven sites) Dual polarity magnetizations are obtained by thermal demagnetızation of samples from the red beds, whereas single polarity directions are observed in the volcanics High unblocking temperatures indicate hematite as the remanence carrier in both the volcanics and sediments These high-temperature, characteristic remanences are easily isolated and pass both the tult and conglomerate tests, they are likely to be of primary Silurian age Characteristic declinations are predominantly northerly and northeasterly, and indicate significant structural rotations on a local scale When the results of the red beds and the volcanics are combined they show characteristic inclinations that are shallower than those of the correlative Botwood Group (ca $36^{\circ}$ vs $43^{\circ}$ ) but not nearly as shallow as those reported from the King George IV Lake area $\left(05^{\circ}\right)$ Mean inclinations obtained from the Springdale red beds are, however, significantly shallower than those of the Springdale volcanics The same difference can be seen in other previous Silurian paleomagnetic studies of central Newfoundland We infer that an inclination error affects the red bed magnetizations of the Springdale Group, Botwood Group (Wigwam Formation) and rocks of the King George IV Lake area Therefore, the results from Silurian red beds should not be used to determine paleolatitudes for central Newfoundland The mean paleolatitude of the Springdale Group volcanıcs is $30^{\circ}$ The mean paleolatitudes for both the Springdale volcanics and Botwood volcanics (Lawrenceton Formation) are indistınguishable withın paleomagnetic error limits from the predicted paleolatitude of Newfoundland on the northeast-trending North American margin Thus, no detectable post-Silurian displacement is shown by the volcanics of the Springdale Group with respect to cratonic North America.
\end{abstract}

\section{Introduction}

The northern Appalachians of Newfoundland may be divided into three main regions, the Humber Zone (Laurentian Margin), the Avalon Zone, and the intervening Central Mobile Belt (CMB). These zones represent the margins of the Ordovician Iapetus Ocean and its remnants. The CMB may be further subdivided into the Dunnage Zone, consisting of the Exploits and Notre Dame Subzones, and the Gander Zone [1], but for the purpose of this study we will use the term CMB (Fig. 1).

Paleomagnetic investigations of the Silurian overlap assemblages in central Newfoundland have yielded shallow and intermediate inclinations. Shallow inclinations are exemplified by the results from the King George IV Lake area [2] and by the results from the Wigwam Formation of the Botwood Group [3, 4]. Intermediate inclinations have been observed from the Lawrenceton Formation of the Botwood Group [3,5]. Paleomagnetic studies of these Silurian units can be useful for the documentation of the tımıng and nature of displacement associated with the closure of Iapetus, but the inclination discrepancies cast doubt on the reliability of these results and they must be resolved before conclusions can be drawn.

Paleolatitudes obtained from Silurian units indicate either significant $\left(\sim 16^{\circ}\right)$ southward (dextral) movement with respect to Laurentia (King George IV Lake area and Wigwam Formation) or no detectable displacement (Lawrenceton Forma- 
tion) of these cover sequences. The significant dextral offset suggested by the shallow directions is of the order of thousands of kilometers and is thus amenable to paleomagnetic documentation. It is important to note that steeper inclinations are predominantly associated with volcanics (Lawrenceton Formation) [3,5], whereas the shallower inclinations are often associated with red beds (King George IV Lake area and Wigwam Formation) $[2,3,4]$. These inclination discrepan- cies would suggest largely different paleolatitudes for coeval Silurian rocks, which is implausible.

In this study we attempt to clarify and resolve this issue, by including both the mafic volcanic rocks of the Silurian Springdale Caldera and the overlying Springdale Group red beds in our paleomagnetic investigation. Whereas the structural corrections can be well determmed for the red beds and somewhat less so for the volcanics, the timing and nature of remanence acquisition may

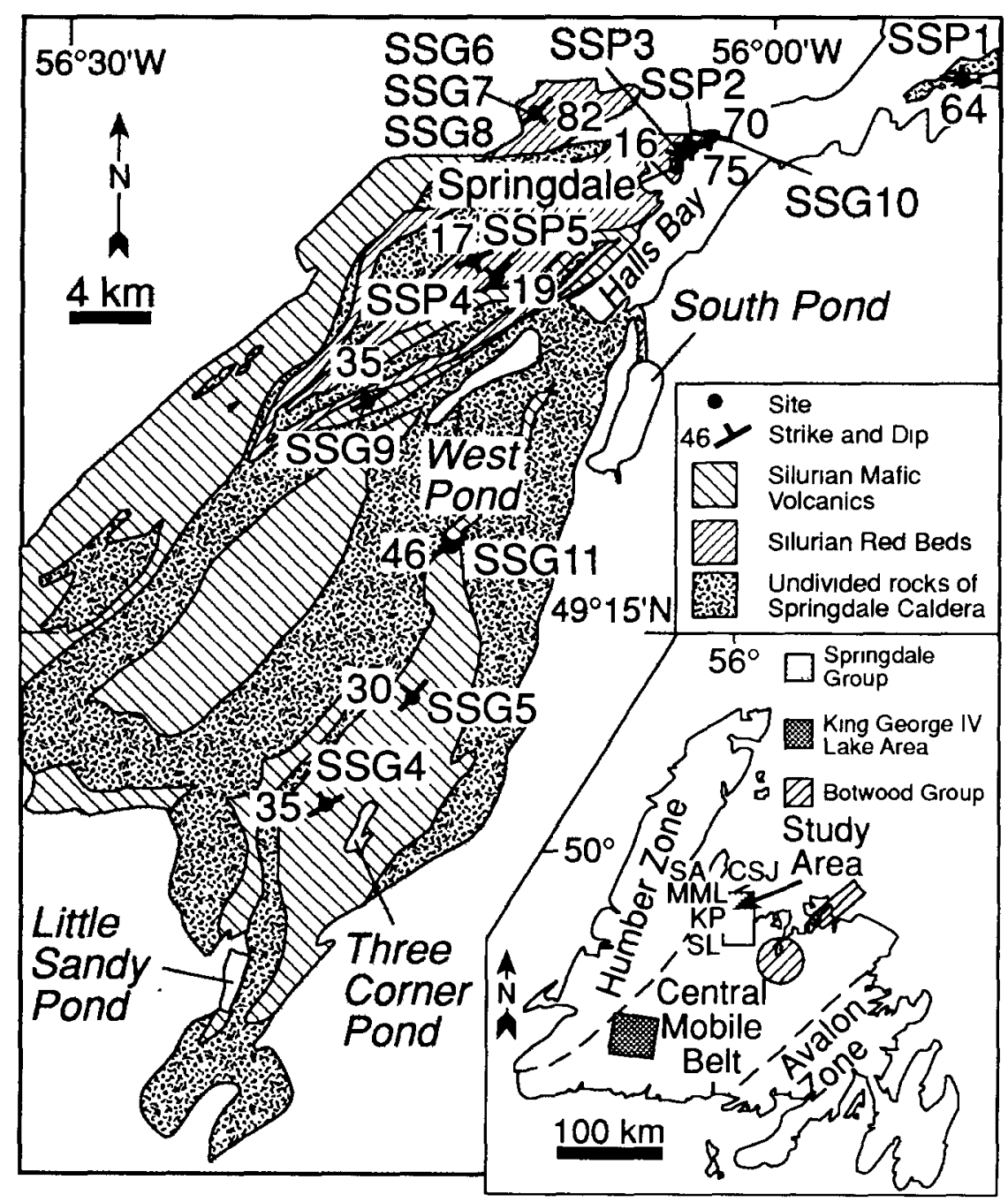

Fig 1. Simplified geologic map of the Springdale Caldera [11], with paleomagnetic site locations Inset. Location map of the Springdale Group study area withın the Central Mobıle Belt of Newfoundland CSI=Cape Saint John Group, $M M L=$ Mıc Mac Lake Group, $K P=$ Kıng's Point Complex, $S L=$ Sheffield Lake Group, $S A=$ Sops Arm Group Together with the Springdale Group, these correlative Early Silurian volcanıc centers form an overlap assemblage lınking the Humber Zone (Laurentian margin) with the western Central Mobile Belt [10,9]. 
be better known for the volcanic rocks. A previous paleomagnetic study of the Springdale Group is the unpublished study of Black [1965, as cited in 2]. This included samples of both volcanics and red beds and resulted in a mean direction of $D=17.7^{\circ}, I=-18.4^{\circ}\left(k=24.7, \alpha_{95}=5.6^{\circ}\right)$ with a corresponding paleomagnetic pole located at $103.7^{\circ} \mathrm{E}, 29.1^{\circ} \mathrm{N}\left(\delta_{\mathrm{p}}=5.8^{\circ}, \delta_{\mathrm{m}}=3.0^{\circ}\right)$. This result must be considered incomplete because it included no more than 28 samples and only AF demagnetization was performed to a maximum of $30 \mathrm{mT}$; it is therefore unlikely that the characteristic remanence, carried by hematite, was isolated. Also, the age of this magnetization is unconstrained as no field tests are reported.

The Springdale Group unconformably overlies the Ordovician Roberts Arm Group [6,7], which has recently been studied by Van der Voo et al. [8]. This submarine volcanic unit has a paleolatitude distinctly different from that of Laurentia $\left(31^{\circ}\right.$ vs. $15^{\circ}$, respectively). The Springdale Group appears to be correlative with surrounding Silurian units: to the northwest, the King's Point Complex; to the north on the Baie Verte Peninsula, the Cape St. John Group; to the west, the Mic Mac Lake and Sheffield Lake Groups; to the west at the southern end of the Humber Peninsula, the Sops Arm Group [9]. The continuity of lower Silurian units in western Newfoundland suggests a linkage of the western Central Mobile Belt to the North American margin by this overlap assemblage $[9,10]$. This study was undertaken firstly to constrain the timing of the docking of CMB terranes in a test of the linkage/overlap situation suggested by the geology, and secondly to examine the disparate inclination results and corresponding paleolatitudes obtained from Silurian red beds and volcanics of the northern Appalachians.

\section{Geologic setting}

The Springdale epicontinental-type collapse caldera extends at least $60 \mathrm{~km}$ along strike and has a maximum width of $35 \mathrm{~km}$ (Fig. 1). This elongate outcrop pattern is parallel to the northnortheast regional fault orientation. The youngest volcanic unit, a nearly massive felsite (unit 10 [11]), is of Early Silurian age based on zircon $\mathrm{U}-\mathrm{Pb}$ ages of $429+6 /-5 \mathrm{Ma}$ and $425 \pm 3 \mathrm{Ma}$ by
Chandler et al. [10] and Coyle and Strong [11] respectively. This youngest volcanic unit is interbedded with red bed sandstone (unit 9 [11]) and is located in the northern section of the outcrop area. This uppermost unit thus yields a minimum age for the Springdale Group. The oldest volcanic unit (unit 1 [11]) within the Springdale Caldera yields a maximum age for the Springdale Group of $432.4+1.7 /-1.4$ Ma based on $\mathrm{U}-\mathrm{Pb}$ zircon geochronology [11]. Thus, the volcanoplutonic events of the Springdale volcanic field took place within a 5 m.y. period between a maximum of 434 and a minımum of $425 \mathrm{Ma}$ [11].

The Springdale Group comprises basaltic flows, andesite flows and pyroclastic rocks, silicic ashflow tuffs, high-silica rhyolite domes, volcanically derived debris flows and breccias, and fluviatile red sandstones and conglomerates [9]. The magmatic activity is envisaged as occurring after the closure of this section of Iapetus in an overall transpressional-extensional tectonic regime [9]. Most of the caldera volcanics are not well exposed; thus we have concentrated our efforts on the mafic volcanics and overlying red beds. The detailed petrology and geochemistry of the Sprıngdale Caldera is presented in Coyle [12] and the sedimentology of the overlying red beds is described by Wessel [13]. To the east and west, the caldera is bounded by upfaulted basement rocks and is intruded by granitoid rocks of the Topsails Complex. To the northwest and northeast it unconformably overlies Lower to Middle Ordovician submarine volcanics. These include the Lush's Bight, Catcher's Pond and Roberts Arm Groups. The latter has yıelded a U-Pb zircon age of $473 \pm 2 \mathrm{Ma}$ [14].

The Springdale Group shows a lack of penetrative deformation (cleavage) and the synform is folded about a gently plunging northeasterly axıs. In the caldera, the beds generally dip gently, but locally dıp as steeply as $50^{\circ}$ [9]. Coyle and Strong [9] have estımated up to $20 \%$ of across-strike regional shortening to account for the present elongate map pattern of the Springdale Group.

\section{Field methods}

Structural attitudes (paleohorizontal) were determined from flows (pillows and flow tops) and interbedded and overlying well-bedded red sedi- 
ments. Sites with varyıng strike and dip were obtained in order to perform a fold test. During the summers of 1989 and 1991, over 120 samples from thirteen sites within the Springdale Group were collected for paleomagnetic study. At least six samples were collected per site. Most samples were drilled in place with a portable gas-powered core drill, and oriented with a magnetıc compass and clinometer. Additional samples were collected as oriented blocks and drilled in the laboratory. The low magnetic intensities of these rocks do not signuficantly affect the magnetic compass readings, as demonstrated in the field by the lack of deflection of the magnetic compass needle.

\section{Laboratory methods}

The cores were cut into standard size paleomagnetic samples $(2.25 \mathrm{~cm} \times 2.5 \mathrm{~cm})$ and stored within a magnetically shielded room at the University of Michigan Paleomagnetic Laboratory. Natural remanent magnetization (NRM) directions were measured on either a ScT two-axis superconducting rock magnetometer or a Schon-

TABLE 1

Springdale Group site means for the characteristic component

\begin{tabular}{|c|c|c|c|c|c|c|c|}
\hline Site & $S / D$ & $N$ & $D / I$ in-situ & $D / I$ tilt-corrected & $\alpha_{95}$ & $k$ & $\begin{array}{l}\text { Paleomag pole } \\
\text { Lat / Long }\end{array}$ \\
\hline \multicolumn{8}{|l|}{ Red beds } \\
\hline SSP1 & $274 / 64$ & 6 & $595 / 194$ & $59 /-18$ & 131 & 271 & \\
\hline SSP2 & $93 / 75$ & 10 & $2711 / 638$ & $209 / 13$ & 99 & 250 & \\
\hline SSP3 & $197 / 16$ & 7 & $186 /-193$ & $24 /-18$ & 120 & 260 & \\
\hline SSP4 & $68 / 17$ & 0 & & & & & \\
\hline SSP5 & $233 / 19$ & 5 & $15 /-248$ & $25 /-35$ & 215 & 136 & \\
\hline SSG6 & $49 / 82$ & 10 & $703 /-248$ & $24 /-22$ & 137 & 135 & \\
\hline SSG8 & $49 / 82$ & 11 & conglomerate & & & & \\
\hline SSG10 & $103 / 70$ & 6 & $2529 /-487$ & $329 /-34$ & 81 & 690 & \\
\hline \multicolumn{8}{|l|}{ Volcanics } \\
\hline SSG4 & $240 / 35$ & 12 & $3522 /-289$ & $11 /-59$ & 30 & 2077 & \\
\hline SSG5 & $220 / 30$ & 10 & $3502 /-44.4$ & $25 /-61$ & 60 & 630 & \\
\hline SSG7 & $49 / 82$ & 7 & $862 /-237$ & $25 /-37$ & 314 & 47 & \\
\hline SSG9 & $240 / 35$ & 12 & $582 /-26.7$ & $75 /-23$ & 42 & 1096 & \\
\hline SSG11 & $240 / 46$ & 14 & $3513 /-76$ & $349 /-42$ & 64 & 396 & \\
\hline \multicolumn{8}{|l|}{ Means } \\
\hline \multirow[t]{2}{*}{ Volcantcs } & & 5 & $226 /-330$ & & 444 & 39 & \\
\hline & & 5 & & $28 /-49$ & 283 & 83 & $7^{\circ} \mathrm{N} / 100^{\circ} \mathrm{E}$ \\
\hline \multirow{2}{*}{ Red beds } & & 6 & $501 /-130$ & & 458 & 31 & \\
\hline & & 6 & & $24 /-26$ & 233 & 92 & $24^{\circ} \mathrm{N} / 98^{\circ} \mathrm{E}$ \\
\hline \multirow[t]{2}{*}{ All sites } & & 11 & $380 /-231$ & & 294 & 34 & \\
\hline & & 11 & & $25 /-36$ & 171 & 81 & $17^{\circ} \mathrm{N} / 99^{\circ} \mathrm{E}$ \\
\hline \multicolumn{8}{|c|}{ Inclination only } \\
\hline \multirow[t]{2}{*}{ Volcanics } & & 5 & -263 & & 208 & 191 & \\
\hline & & 5 & & -44 & 256 & 129 & \\
\hline \multirow[t]{2}{*}{ Red beds } & & 6 & -82 & & 584 & 22 & \\
\hline & & 6 & & -19 & 229 & 110 & \\
\hline \multirow[t]{2}{*}{ All sites } & & 11 & -210 & & 24 & 43 & \\
\hline & & 11 & & -31 & 17 & 78 & \\
\hline
\end{tabular}

$S / D=$ strike and dip (right-hand rule), $N=$ number of thermally demagnetized samples used to calculate the site mean, $D / I=$ declination and inclination $\left(^{\circ}\right), \alpha_{95}=$ radius of cone of confidence [17,23], $k=$ estımate of Fisher precision parameter [17,3] 
stedt SSM-1A spinner magnetometer. Alternating field demagnetizations of the NRM were performed with either a Schonstedt GSD-1 singleaxis AF demagnetizer or a Sapphire Instruments SI-4 AF single-axıs demagnetizer. Thermal demagnetization was conducted using a Schonstedt TSD-1 furnace, and the temperatures presented have been recalculated based on a 1991 recalibration of the thermal demagnetizer. Alternatıng field demagnetization of pilot samples failed to resolve multiple components of remanence and left a significant portion of high-coercivity NRM intensity even after applied fields of $170 \mathrm{mT}$. We therefore performed thermal demagnetization in this study. Thermal demagnetization from room temperature (NRM) to approximately $700^{\circ} \mathrm{C}$ used between 15 and 30 steps.

Principal component analysis [15] was used to fit lines and planes (great circles) to the components identified by inspection of the orthogonal vector diagrams [16]. A minimum of at least three points were fit by the lines and planes and the maximum acceptable mean angular deviation (MAD) was chosen to be $15^{\circ}$. Site means and a formation mean are presented with their respective $\alpha_{95}$ cones of confidence and precision parameter $k[17]$ in Table 1.

\section{Results}

Natural remanent magnetizatıon (NRM) intensities range from 1 to $15 \mathrm{~mA} / \mathrm{m}$ for the red bed samples and from 50 to $2000 \mathrm{~mA} / \mathrm{m}$ for the volcanic samples. Northerly and steeply downward directions from some samples suggest a partial present day field (PDF) direction overprint, but the corresponding NRM directions differ from the present-day field direction, indicating that the characteristic remanence has not been completely overprinted by a viscous magnetization of recent origin. Other samples exhibit northerly and shallow upward directions that resemble the characteristic direction, as will be shown later.

\subsection{Demagnetization}

In general, the demagnetization trajectories of the volcanic samples are very well behaved, whereas those of red bed samples are more noisy, which may account for the larger $\alpha_{95}$ confidence circles associated with the red bed sites. The demagnetization behavior of the red bed samples is illustrated by samples SSP2.6 and SSP3.7 (Fig. $2 \mathrm{a}$ and b). Sample SSP2.6 exhibits removal of a component (present-day field overprint in $\mathrm{m}$-situ coordinates) at fairly low temperatures, followed by a univectoral trend to the origin with an unblocking temperature spectrum between 640 and $673^{\circ} \mathrm{C}$. Sample SSP3.7 exhibits a curved trajectory at fairly low unblocking temperatures during the removal of a steep (present-day field?) overprint. As with the previous example the sample exhibits a range of unblocking temperatures between 625 and $673^{\circ} \mathrm{C}$.

The demagnetization behavior of the volcanic samples is illustrated by samples SSG11.12 and SSG5.6 (Fig. 2c and d). Sample SSG11.12 exhibits a near-univectorial orthogonal vector projection and complete removal of the NRM is not attained until $673^{\circ} \mathrm{C}$. This clean behavior is characteristic of many of the volcanic samples. Sample SSG5.6 exhibits linear demagnetization as well as high unblocking temperatures up to $687^{\circ} \mathrm{C}$ and is also illustrative of the demagnetization behavior of the volcanics.

Dual polarity characteristic magnetizations are observed in the red beds whereas only a single polarity has been found in the volcanics. The presence of a red bed site (SSP2) with reversed directions that are nearly antıpodal to the mean direction suggests that paleosecular variation has been adequately averaged.

The characteristic magnetization is carried by hematite, as can be concluded from the distinctive high-temperature unblocking spectra and the failure of AF demagnetization to remove more than half of the NRM intensity. Also, IRM experiments fail to magnetically saturate either the red bed or volcanic samples, even at peak fields up to $1.4 \mathrm{~T}$.

\subsection{Conglomerate test}

Paleomagnetic cores were collected from eleven clasts of volcanic rock in an upper unit of puddingstone conglomerate within the Springdale Group red beds. Individual clasts show similarities to, as well as differences from, the demagnetization behavior of individual samples of Spring- 
dale Caldera volcanics. Similarities include hightemperature (hematite) unblocking spectra, whereas differences include trajectories that are curved to a greater degree at low temperatures as well as noisier high-temperature behavior.

As shown in the stereogram (Fig. 3) these high-temperature stable end point directions are randomly oriented, thus demonstrating that this unit has not been remagnetized since the time of deposition [18]. This conglomerate test is random at the $95 \%$ significance level, as the calculated resultant ( $R=1.66$ ) is less than the expected value $\left(R_{\mathrm{o}}=5.28\right)[19,20]$. The distribution of magnet1zation directions may be termed random, as the length of the resultant vector $(R)$ is less than $R_{\mathrm{o}}$, where $R_{\mathrm{o}}$ is the value of $R$ that will be exceeded with a probability of $5 \%$ by a sample drawn from a random population. Thus, the characteristic high-temperature remanence direction passes the conglomerate test.

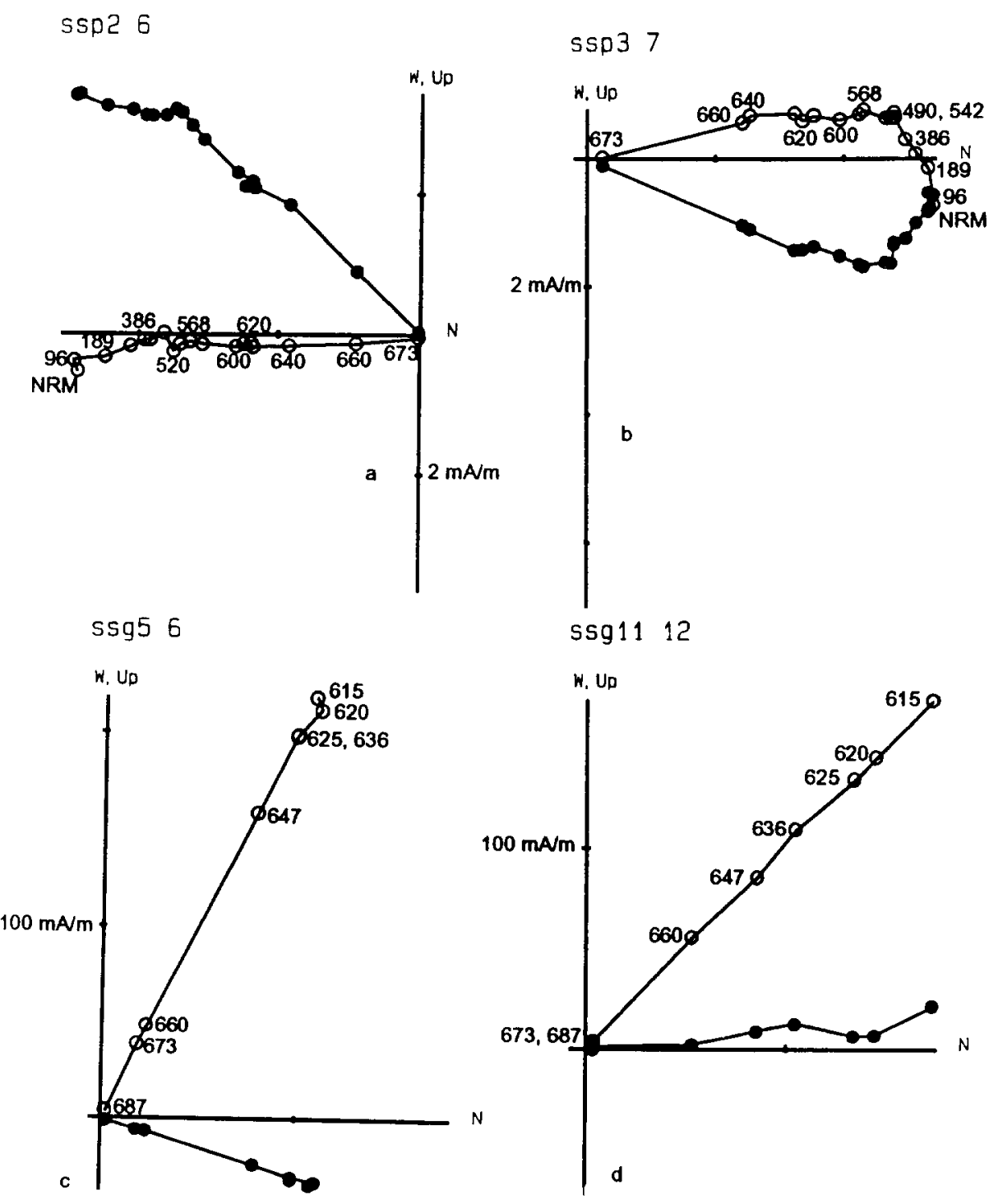

Fig 2 Tilt-corrected orthogonal vector projectıons of thermal demagnetızation behavior for Springdale Group red bed samples SSP2 6 (a) and SSP3 7 (b) and volcanic samples SSG5 6 (c) and SSG11 12 (d) $\bullet=$ projections of the horizontal component, $\mathrm{O}=$ projections of the vertical component 


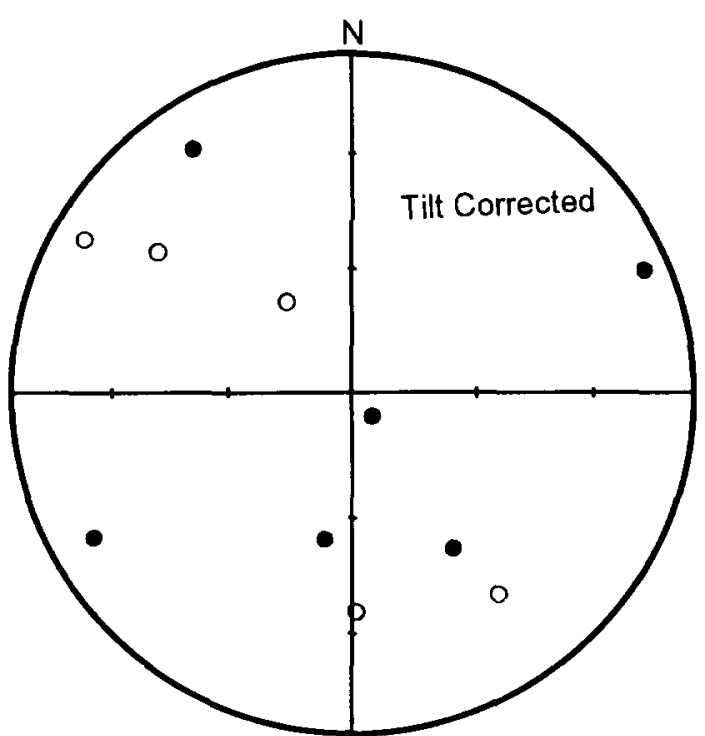

Fig 3 Tilt-corrected equal-area stereogram illustrating the positive conglomerate test for site SSG8. $\bullet=$ projections on the lower hemisphere; $O=$ projections on the upper hemısphere These high-temperature stable end point directions from volcanic clasts $(N=11)$ pass the conglomerate test The calculated resultant $(R=166)$ is less than predicted $\left(R_{\mathrm{o}}=\right.$ 528 ), where $R_{\mathrm{o}}$ is the value that will be exceeded with a probability of $5 \%$ when sampling from a random population $[19,20]$

\subsection{Tilt test}

The site mean directions for volcanics and red beds combined cluster better after tilt correction (in-situ: $D / I=38.0^{\circ} /-23.1^{\circ}, k=3.4, \alpha_{95}=29.4$, $n=11$ sites; tilt-corrected: $D / I=25^{\circ} /-36^{\circ}, k=$ 8.1, $\left.\alpha_{95}=17.1, n=11\right)$. The tectonic correlation fold test of McFadden [21] yields a value (SCOS $=3.861)$ that is nearly equal to the $95 \%$ confidence value (3.865). Thus there is no reason to reject, at nearly the $95 \%$ confidence level, the hypothesis that the characteristic magnetization was acquired before folding. This suggests a pretiltıng age of magnetization (Fig. 4) and the lack of a dramatic improvement in clustering is attributable to the wide between-site scatter of declinations. We have analyzed this declination variation by comparing it with the regional variation in strike in an attempt to account for any subsequent regional warping of the Springdale Caldera, but this analysis has not yielded a coherent pattern. The calculated paleomagnetic pole $\left(17.3^{\circ} \mathrm{N}, 99.1^{\circ} \mathrm{E} ; \delta_{\mathrm{p}}=11.5^{\circ}, \delta_{\mathrm{m}}=19.9^{\circ}\right)$ plots close to the Siluro-Devonian reference poles [22] (Fig. $5)$.

The formation mean may be divided into red bed and volcanic site submeans (see Table 1). Because we believe that the declinations have been scattered by later structural disruption we have also calculated the mean inclinations without regard to declination. The method of McFadden and Reid [23] was used to calculate $k, \alpha_{95}$ and the mean inclinations. These mean inclinations are as follows:

For all sites: in-situ $-21.0 \pm 24.0^{\circ}$, tilt-corrected $-31 \pm 17.0^{\circ}(n=11$ sites $)$

For red bed sites: in-situ $-8.2 \pm 58.4$, tilt-corrected $-19 \pm 22.9^{\circ}(n=6$ sites $)$

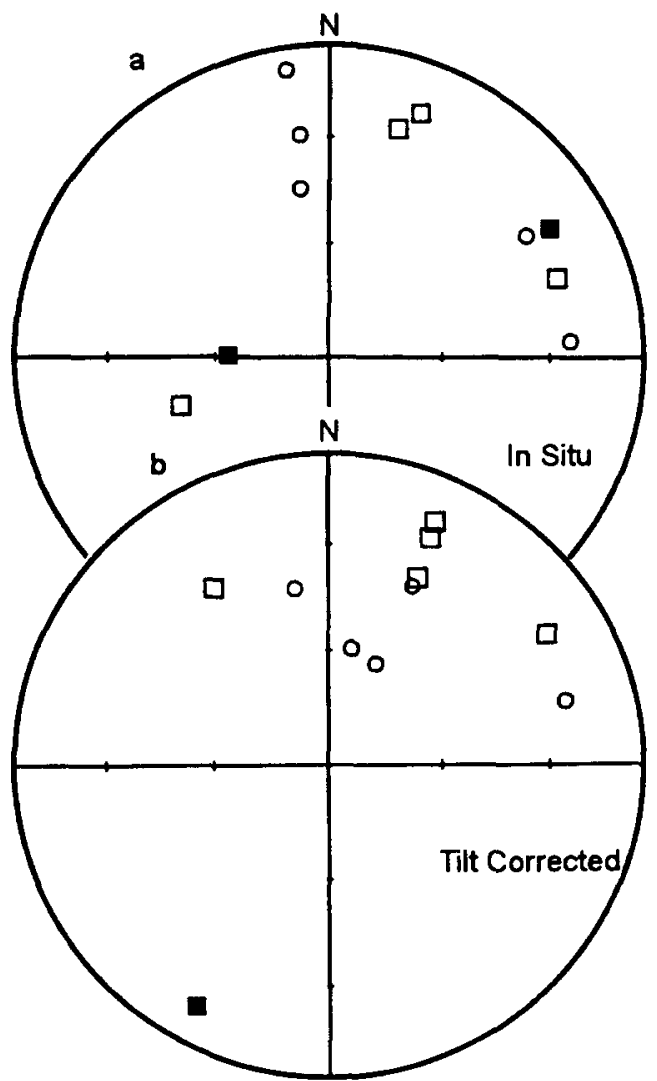

Fig. 4 Equal-area stereograms for all Springdale Group site means in in-situ (a) and tilt-corrected coordinates (b) In-situ mean $D / I=380^{\circ} /-231^{\circ}\left(k=34, \alpha_{95}=294\right)$ Tilt-corrected mean $D / I=25^{\circ} /-36^{\circ}\left(k=81, \alpha_{95}=171\right)$ The squares/circles correspond to red bed/volcanic sites Solid/ open symbols are projections on the lower/upper hem!sphere 


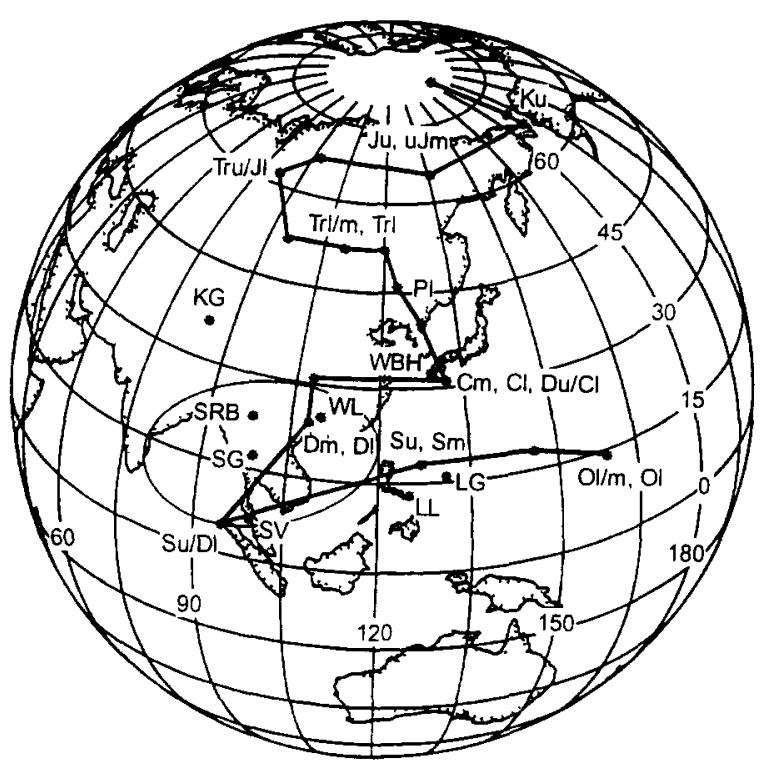

Fig 5 APWP for North America comprising mean paleopoles with $Q \geqslant 3$ after Van der Voo [22] $L L=$ Lawrenceton Formation of Lapointe [3] $\left(13^{\circ} \mathrm{N}, 125^{\circ} \mathrm{E}\right) ; L G=$ Lawrenceton Formation of Gales et al [5] $\left(16^{\circ} \mathrm{N}, 131^{\circ} \mathrm{E}\right), K G=$ King George IV Lake ared of Buchan and Hodych [2] $\left(359^{\circ} \mathrm{N}, 846^{\circ} \mathrm{E}\right)$, $W B H=$ Wigwam Formation of Buchan and Hodych [4] $\left(323^{\circ} \mathrm{N}, 1292^{\circ} \mathrm{E}\right), W L=W_{1}$ gwam Formation of Lapointe [3] $\left(25^{\circ} \mathrm{N}, 110^{\circ} \mathrm{E}\right) ; S R B=$ Springdale red beds of this study $\left(24^{\circ} \mathrm{N}\right.$, $\left.98^{\circ} \mathrm{E}\right), S V=$ Springdale volcanics of this study $\left(7^{\circ} \mathrm{N}, 100^{\circ} \mathrm{E}\right)$, $S G=$ combined Springdale Group of this study $\left(17^{\circ} \mathrm{N}, 99^{\circ} \mathrm{E}\right)$ with confidence ellıpse

For volcanic sites: in-situ $-26.3 \pm 20.8^{\circ}$, tilt-corrected $-44 \pm 25.6^{\circ}(n=5$ sites $)$.

\section{Discussion}

The positive conglomerate and tilt tests and the presence of reversals lead us to conclude that the characteristic magnetization of the Springdale Group is a primary magnetization. In addition, the paleomagnetic pole does not closely resemble post-Devonian paleomagnetic poles from North America as might be expected if the magnetization were representative of a late remagnetization event.

While the individual site means show good agreement in inclination, the declinations vary significantly. This may be due to differential block rotations upon collapse of the caldera and the subsequent structural elongation of the caldera [9] or later (Devonian-Carboniferous) strike-slip movements [11]. For our analysis we are concerned only with the paleolatitude of the Springdale Group, which is derived solely from the average inclination and is thus relatively independent of the declinations. When the results from the red beds and volcanics are combined the resulting paleolatitude is $20^{\circ} \mathrm{S}$, which is indistingushable from the predicted location of Newfoundland on the North American margin for this time.

We have plotted the paleolatitude of the Springdale Group in Fig. 6 for comparison with predicted paleolatitudes determined from North America, Avalon, and the intervening CMB terranes. All paleolatitudes are calculated for an average Springdale location $\left(49.3^{\circ} \mathrm{N}, 303.7^{\circ} \mathrm{E}\right)$. Those from Avalon (the large dots) include values from southern Britain $[24,25]$ that have been calculated from the poles after they have been rotated into North American coordinates so as to close the Atlantic Ocean.

One can see a wide separation between North America and Avalon during the Early Ordovician. This separation gradually diminishes until there is no distinguishable paleolatitudinal differ-

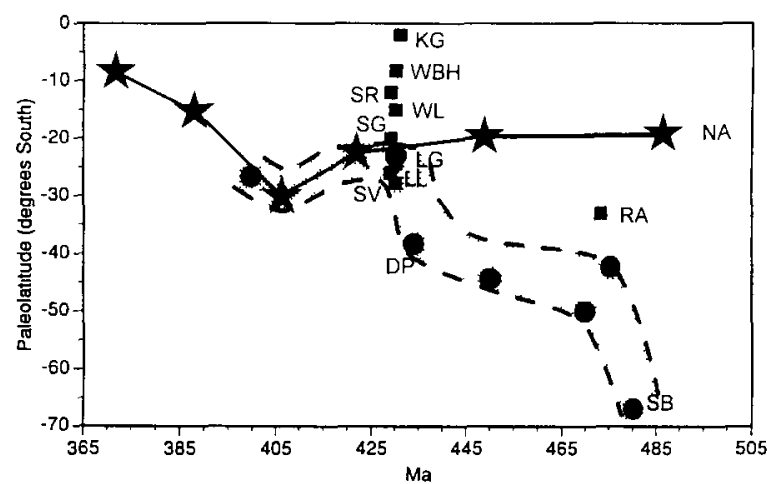

Fig 6 Predicted paleolatitudes calculated for Springdale, Newfoundland $\left(493^{\circ} \mathrm{N}, 3037^{\circ} \mathrm{E}\right)$ Included are those from central Newfoundland ( $\boldsymbol{\square}$ ), North America $(\star)$ and Avalon (•) The Avalon path is highlighted by the stippled area $S G=$ Springdale Group, $S R=$ Springdale red beds, $S V=$ Springdale volcanics, $L G=$ Lawrenceton Formation of Gales et al [5], $L L=$ Lawrenceton Formation of Lapointe [3], $K G$ = King George IV Lake area of Buchan and Hodych [2], $W L=$ Wigwam Formation of Lapointe [3], $W B H=W_{1}$ igwam Formation of Buchan and Hodych [4], $R A=$ Roberts Arm Group of Van der Voo et al [8], $N A=$ North America [22], $S B=$ eastern Avalon (southern Britain) $[24,25], D P=$ western Avalon (Dunn Point volcanıcs, Nova Scotia) [34]. 
TABLE 2

Silurian southern hemisphere paleolatitudes from central Newfoundland calculated for the Springdale locality

\begin{tabular}{lcl}
\hline Unit & Red beds & Mafic volcanıcs \\
\hline King George IV Lake & $14 \pm 9^{\circ}[26]$ & \\
& $2 \pm 6^{\circ}[2]$ & \\
Springdale Group & $10+14 /-12^{\circ}$ & $26+27 /-17^{\circ}$ \\
Botwood Group. & $8 \pm 6^{\circ}[4]$ & $24 \pm 6^{\circ}[5]$ \\
& $15 \pm 9^{\circ}[3]$ & $28 \pm 8^{\circ}[3]$ \\
\hline
\end{tabular}

ence in the Silurian. The Roberts Arm Group paleolatitude [8] is shown for comparison because this Ordovician terrane underlies the Springdale Group. The wide spread in paleolatitudes determined from Early Silurian units is clearly apparent. These paleolatitudes range from $2^{\circ} \mathrm{N}$ for the King George IV Lake area [2] to $27^{\circ} \mathrm{S}$ for the Lawrenceton volcanics of the Botwood Group [3].

Table 2 lists the paleolatitudes of all Silurian studies of central Newfoundland rocks. The Wigwam Formation of the Botwood Group, studied by Lapointe [3] and Buchan and Hodych [4], consists mainly of red beds. In the former study the Wigwam red beds have shallower inclinations than the Lawrenceton volcanics of the same group $\left(28^{\circ}\right.$ vs. $\left.47^{\circ}\right)$. In the King George IV Lake area the mean of three sites of volcanics is $10^{\circ}$ steeper than the mean of seven sites of red beds [2]. A more recent study of red beds from the King George IV Lake area yields a low paleolatitude similar to that obtained from the Springdale red beds $\left(14 \pm 9^{\circ}\right)$ [26]. Finally, our mean inclination of the Springdale volcanics ( $n=5$ sites) is $25^{\circ}$ steeper than that of the Springdale red bed sites $(n=6$ sites). Hodych and Buchan have reported, in abstract form, similar shallow inclınations from the red beds of the Springdale Group [27]. The only exception to this general pattern is a shallower inclination (by $5^{\circ}$ ) for three felsic flows included in the Wigwam Formation study of Buchan and Hodych [4]. Although the pattern of shallower inclinations in red beds is farrly consistent, it should be noted that the $\alpha_{95}$ 's are generally large, so that many of these differences in inclination are within the statistical uncertainty. Nevertheless, it remains an important issue because the low red bed paleolatitudes relative to North America have geologic implications which may include thousands of kilometers of south- ward (dextral) strike-slip motion, which seems geologically implausible.

We will now discuss two categories of possible explanations for the discrepancies in inclinations and their associated paleolatitudes. The first category includes possible problems with the individual studies. The shallower inclinations associated with the red beds may indicate shallowing of an initial DRM, p-DRM or rapidly acquired CRM $\left(<10^{3}\right.$ yrs $)$ due to compaction, as suggested for the Wigwam Formation red beds by Van der Pluijm et al. [28]. Compaction and the associated shallowing of inclination are most likely to occur in fine-grained sediments that are not cemented before significant burial. During paleomagnetic sampling it is common to preferentially sample such fine-grained red beds. In the case of the Springdale red beds the fairly straightforward demagnetization behavior may indicate that NRM acquisition was indeed farrly rapid [29]. Such an early NRM would be susceptible to inclination shallowing upon subsequent burial. In contrast, compaction is negligible in the volcanics of the Lawrenceton Formation studied by Gales et al. [5] and Lapointe [3]. Problems in these studies of volcanic rocks may include the following:

(1) Paleosecular variation may not be adequately averaged. For mafic volcanics, it has been shown that the actual number of distinct VGPs may be significantly less than the number of flows [30], thus requiring significantly more sites than flows to adequately average paleosecular variation. The very large differences in inclination $\left(>30^{\circ}\right)$, however, cannot be accounted for by this explanation [31].

(2) The structural corrections from volcanic flows are not as precise as those obtained from sedimentary units (red beds). Imprecise structural correction may account for greater scatter between sites and studies, but not for the consistently higher inclinations exhibited by the volcanics.

(3) The red beds may have acquired their characteristic magnetization after that acquired by the volcanics. The age of red bed magnetızation has been shown to be pre-folding but not necessarily to pre-date the formation of the conglomerates. The conglomerate tests in all studies sampled volcanic clasts and thus limit the timing of magnetization acquisition in the 
volcanic units and not the red beds themselves. Thus, any possible remagnetization of the red beds is constrained to be older than the folding, which is pre-Late or Late Silurian in age [32]. Elliot et al. [32] have used U-Pb geochronology to constrain three generations of folds in north-central Newfoundland to be no younger than the cross-cutting tonalite dike swarms $(408 \pm 2 \mathrm{Ma})$.

The second category of explanations includes actual latitudinal offset of these terranes relative to North America. If one regards the Lawrenceton volcanic results as questionable, one may postulate a large dextral offset between the Springdale Group and the King George IV Lake area. A fundamental terrane boundary between the Humber Zone and the CMB must then be postulated between the Springdale Caldera and the King George IV Lake area. Yet the differences seen between red beds and volcanics from the same group (e.g., Springdale and Botwood Groups) would require that the displacement occurred after the volcanics were deposited.

We prefer the explanation of inclination shallowing, because the latitudinal offset hypothesis is geologically less plausible [11]. A mean compaction of the Springdale red beds of $57 \%$ would account for the $23^{\circ}$ difference in mean inclination between the two rock types. This degree of compaction is comparable with the nearly $50 \%$ compaction determined from thin section observations of a highly compacted lithic sandstone [33]. Inclination shallowing in the red beds seems to explain most of the inclination discrepancies between Silurian red bed and volcanic units, and avoids the need for large-scale Silurian displacements in central Newfoundland. This conclusion is also supported by the aforementioned Silurian overlap assemblage [10] in that it would link the $\mathrm{CMB}$ and the Humber Zone.

In conclusion, the inclinations derived from the Springdale Group red beds and other Silurian red beds from central Newfoundland should not be used to determine paleolatitudes due to their anomalously shallow inclinations. The nature and occurrence of these inclination discrepancies, however, requires further study within central Newfoundland The mean paleolatitude derived from the Springdale Group volcanics is $30^{\circ}$, which is indistinguishable from the predicted North

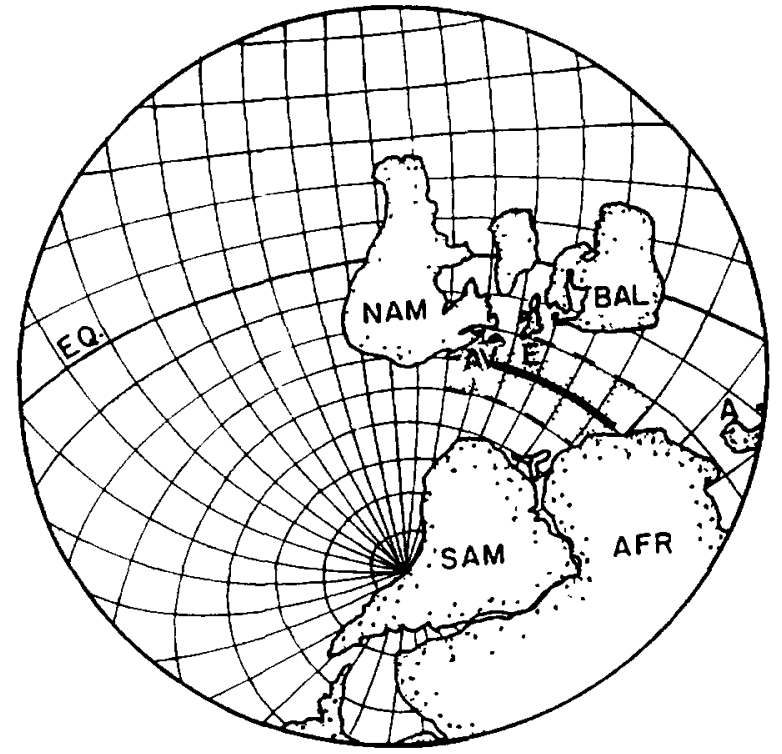

Fig. 7 Silurian paleogeographic reconstruction of the lapetus Ocean [35] $A=$ Armorica; $A F R=$ Africa, $A V=$ Avalon, $B A L=$ Baltica $E=$ southern Britain, $N A M=$ North America, $S A M=$ South America The paleolatitude $\left(30^{\circ} \mathrm{S}\right)$ of the Springdale Group is represented by the stippled area, which includes a minımum error estımate of $\pm 10^{\circ}$ This paleolatitude is indistingushable from the Laurentian margin and suggests that the western Central Mobile Belt was accreted to Laurentia by the begınning of the Wenlock The calculated minımum north-south closure velocity for the interval 470-430 $\mathrm{Ma}$ is $35-40 \mathrm{~cm} / \mathrm{yr}$, as calculated from the paleolatitudes of the Roberts Arm Group [8] and this study

American paleolatıtude for the Springdale location (Fig. 7). These results imply that the western CMB was accreted to Laurentia by the Middle Silurian and that any post-Silurian latıtudinal displacement is beyond the limits of paleomagnetic detection.

\section{Acknowledgements}

The fieldwork conducted during 1991 by the first author was supported by a Geological Society of America Research Grant and the Scott Turner Fund of the University of Michıgan. Laboratory work was supported by the National Science Foundation Division of Earth Sciences (grants EAR 89-05811 and EAR 91-18021). We thank R.J.E. Johnson for prelimınary fieldwork during the summer of 1989, J.T. McCaw for assistence with sample preparation and measurement, 
J. Stamatakos for providing computer programs, and D. Austin for drafting some of the figures. M. Coyle and S. Mara Pudifin are thanked for helpful discussions on the geology of central Newfoundland. Maps were provided by the Newfoundland Department of Forestry and Agriculture and the Geological Survey Branch, Department of Mines and Energy. We also thank C. Langmuir and two anonymous referees for helpful comments.

\section{References}

$1 \mathrm{H}$ Willams, S P Coleman-Sadd and H S Swınden, Tectonic-stratıgraphic subdivisıons of central Newfoundland, in Current Research, Part B, Geol. Surv Can Pap 88-1B, 91-98, 1988

2 K L Buchan and J P. Hodych, Early Silurian paleopole for redbeds and volcanics of the King George IV Lake area, Newfoundland, Can J. Earth Scl. 26, 1904-1917, 1989

3 P L Lapointe, Paleomagnetısm and orogenic history of the Botwood Group and Mount Peyton Batholith, Central Mobıle Belt, Newfoundland, Can J Earth Scı 16, 866-876, 1979

4 K L Buchan and J P Hodych, Early Sılurian paleolatıtude for central Newfoundland from paleomagnetssm of the Wigwam Formation, Can J Earth Sci 29, 1652-1661, 1992

$5 \mathrm{JE}$ Gales, B A van der Pluım and R Van der Voo, Paleomagnetssm of the Lawrenceton Formation volcanic rocks, Silurian Botwood Group, Change Islands, Newfoundland, Can J Earth Scı 26, 296-304, 1989

$6 \mathrm{HH}$ Bostock, The Roberts Arm Group, Newfoundland Geological notes on a Middle or Upper Ordovician island arc environment, Geol. Surv Can Pap 78-15, 21 pp, 1978

7 H H Bostock, Geology and petrochemistry of the Roberts Arm Group, Notre Dame Bay, Newfoundland, Geol Surv Can Bull $369,84 \mathrm{pp}, 1988$

8 R Van der Voo, R J E Johnson, B A. van der Pluım and L C Knutson, Paleogeography of some vestıges of Iapetus Paleomagnetism of the Ordovician Robert's Arm, Summerford, and Chanceport Groups, central Newfoundland, Geol Soc Am Bull 103, 1564-1575, 1991

$9 \mathrm{M}$ Coyle and D.F Strong, Geology of the Springdale Group a newly recognized Silurian epicontınental-type caldera in Newfoundland, Can J Earth Sc1 24, 1135-1148, 1987

$10 \mathrm{~F} \mathrm{~W}$ Chandler, R W Sullivan and K L Curre, The age of the Springdale Group, western Newfoundland, and correlative rocks-evidence for a Llandovery overlap assemblage in the Canadian Appalachians, Trans R. Soc Ed1nb , Earth Scı 78, 41-49, 1987

11 M Coyle and D Strong, Geology of the Silurian Springdale Caldera, King's Point-Sheffield Lake Complex and spatially associated suites, Geol Surv Can Open File 2456, 1992
12 M Coyle, Geology, geochemistry, and geochronology of the Springdale Caldera, Ph D Thesis, Memorial Unıv, St John's, Nfld , 1990

13 J M Wessel, Sedımentary petrology of the Springdale and Botwood Formations, Central Mobile Belt, Newfoundland, Canada, Ph D Thesis, Univ Massachusetts, Amherst, Mass, 1975

14 G R Dunnıng, B F Kean, J G Thurlow and H S Swinden, Geochronology of the Buchans, Roberts Arm, and Victoria Lake Groups and Mansfield Cove Complex, Newfoundland, Can J Earth Scı 24, 1175-1184, 1987

15 J L Kurschvınk, The least-squares line and plane and the analysıs of paleomagnetic data, Geophys J R Astron Soc $62,699-718,1980$

16 J D A Z Z jerveld, AC demagnetızation of rocks Analysıs of results, in Methods in Paleomagnetısm, D W Collınson, K M Creer and S K Runcorn, eds, pp 254-286. Elsevier, Amsterdam, 1967

17 R A Fisher, Dispersion on a sphere, Proc R Soc London, Ser A 217, 295-305, 1953

$18 \mathrm{~J} \mathrm{~W}$ Graham, The stability and significance of magnetısm in sedimentary rocks, J Geophys Res 54, 131-167, 1949

19 G S Watson, A test for randomness of directions, Mon Notices R Astron Soc, Geophys Suppl 7, 153-159, 1956.

20 E Irving, Paleomagnetısm and its Application to Geological and Geophysical Problems, Wiley, New York, 1964

21 P L McFadden, A new fold test for paleomagnetic stud1es, Geophys J Int 103, 163-169, 1990

$22 \mathrm{R}$ Van der Voo, Phanerozolc paleomagnetic poles from Europe and North America and comparisons with cont1nental reconstructions, Rev Geophys 28, 167-206, 1990

23 P L McFadden and A B Reid, Analysıs of paleomagnetıc inclination data, Geophys J R Astron Soc 69, 307-319, 1982

24 C McCabe, J E T Channell and N H Woodcock, Further paleomagnetic results from the Bulth Wells Ordovician Inlıer, Wales, J Geophys Res 97, 9357-9370, 1992

25 J E T Channell, C McCabe, T H Torsvik, A Trench and NH. Woodcock, Paleozolc paleomagnetic studies in the Welsh Basın-recent advances, Geol Mag 129 (5), 533542,1992

26 S Potts, B van der Pluijm and R Van der Voo, Discordant Silurian paleolatitudes for Central Newfoundland, Eos, Trans Am Geophys. Union 74 (16), 118, 1993

$27 \mathrm{~J} \mathrm{P}$ Hodych and KL Buchan, Paleomagnetism of red beds of the Early Silurian Springdale Group and its bearing upon closure of the Iapetus Ocean in central Newfoundland, Geol Assoc Can Program Abstr 17, A49, 1992

28 B A van der Pluym, R Van der Voo, S S Potts and J Stamatakos, Early Silurian paleolatitude for central Newfoundland from paleomagnetism of the Wigwam Formation Discussion, Can J Earth Sci 30, 644-645, 1993

29 R F Butler, Paleomagnetısm, Blackwell, Boston, 1992

$30 \mathrm{G} \mathrm{J}$ Calderone, R.F Butler and G D Acton, Paleomagnetısm of Middle Miocene volcanıc rocks in the MojaveSonora Desert region of western Arizona and southeastern Calıfornua, J Geophys Res 95, 625-647, 1990

31 K L Buchan and J P Hodych, Early Silurian paleolatıtude 
for central Newfoundland from paleomagnetism of the Wigwam Formation Reply, Can J Earth Sc1 30, 645-646, 1993

32 C G Ellıtt, GR Dunnıng and PF Wılladms, New U/Pb zurcon age constrants on the timing of deformation in north-central Newfoundland and implications for early Paleozoic Appaldchian orogenısıs, Geol Soc Am Bull $103,125-135,1991$

33 E G Ehlers and H Blatt, Petrology Igneous, Sedımentary, and Metamorphic, Freeman, New York, 1982
34 R J E Johnson and R Van der Voo, Prefolding magnet1zation reconfirmed for the Late Ordovician-Early Silurian Dunn Point volcanıcs, Nova Scotıa, Tectonophysıcs 178, 193-205, 1991

35 R Van der Voo, Paleomagnetssm of the Atlantıc, Tethys and Iapetus Oceans, Cambridge Univ Press, New York, 1993 